\title{
1. Introduction: the challenges of collaboration in environmental governance
}

\section{Richard D. Margerum and Cathy J. Robinson}

Around the world a host of collaborative strategies and approaches have been initiated to address some of the most complex, contentious and difficult environmental issues facing society today. Although there are now diverse purposes, forms and functions of collaborative approaches to environmental governance, each share mechanisms to enable the integration of knowledge, activities and perspectives of diverse actors to improve management decisions. They have been initiated because long-standing conflict and competition over resources has led to untenable situations and pressures for change. They have also been initiated because the types of problems and solutions have changed.

This book encompasses a diversity of experiences and scholarship focused on collaborative approaches to environmental governance and shows that collaboration has rapidly evolved from an emerging concept to a leading practice and paradigm. The rationale behind collaboration is clear. Collaboration between institutions at multiple jurisdictional levels, and with multiple perspectives and epistemologies, can lead to benefits of shared responsibility for management decisions, trust and social learning to create adaptive, innovative and mutually agreed solutions. It can also produce institutional flexibility to manage multiple stakeholder interests and knowledge that can respond to the interconnectedness of socialecological systems which shape and are shaped by the context and nature of environmental decisions.

Over the past few decades the theoretical pedigree of collaboration has grown based on academic roots in governance, public participation, planning, conflict resolution, resilience and public management to create theories and principles that not only reflect disciplinary foci but also the countries in which this scholarship has grown. Just as importantly, rapid application and experimentation has propelled collaboration to the forefront of governance and management practice. With or without the 
theories to guide them, practitioners have been engaged in collaboration on an increasing basis. Stakeholders, decision makers and scientists alike recognized that at the heart of the collaborative governance imperative has been the need to strengthen the link between the diversity of knowledge and the range of actions for addressing some of the most complex and wicked environmental issues of our era.

As this body of scholarship and practice matures, it is timely to consider the challenges of collaborative approaches to environmental governance. This volume highlights how these challenges reflect the variety of perspectives and experiences that are brought together. Conflict is the prelude to consensus and debate about the efficacy of collaboration is rarely fully resolved. It is within this debate that these chapters focus on new innovations and adaptations needed for collaboration to create the social and institutional conditions for changes needed for sustainability.

\section{THE CHALLENGE OF COLLABORATION}

This book grew out of an ongoing conversation among researchers addressing collaborative governance and practitioners working to make collaboration more effective. As chapters in this volume highlight, the empirical research on the practice of collaboration is increasing in sophistication, breadth and detail. Models, evaluation frameworks and principles to examine collaborative environmental governance now exist based on a range of methods, academic traditions and settings. The success of collaboration has been celebrated, but there is less research on the difficulties and challenges of collaborative planning and policy.

In recent years there is a small but growing body of literature that takes a more critical view of collaboration (Echeverria, 2001; Hanemann and Dyckman, 2009; Layzer, 2008; Lubell, 2004). In part this reflects the increased complexity and competition over the management of natural resources that is demanding more of collaborative processes and partnerships. It also reflects the diversity of purposes, decision-making levels and types of collaborative governance arrangements that influence the types of barriers that collaborative partners will face (Margerum and Robinson, 2014). This research highlights significant hurdles that collaborators face because different stakeholders have different needs, missions and mandates. Thus, from the outset, collaborative processes and arrangements confront barriers and challenges related to power sharing and consensus building, particularly when the issues and context offer more trade-offs and fewer opportunities for joint gains.

Our goal with this book is to bring together a wide range of researchers 
from different disciplines and different countries to examine the challenges of collaboration from a variety of perspectives. We have sought out authors who have explored these challenges in theory, those engaged in empirical research, and those exploring new ways of practicing collaboration. We did not start this book with a pre-identified set of challenges, but instead sought out a range of authors who could offer different perspectives. All the authors approached the task of unpacking the challenges facing collaboration with a view that the combined work will lead to better collaborative approaches and strategies.

In this chapter, we seek to set the context for collaborative approaches to governing environmental problems by presenting the emergence of the concept and academic traditions from Europe, the United States and postcolonial countries like Australia and India. We follow this with a brief summary of three terms that form the themes for this book: challenges, collaboration and governance. This is followed by an overview of the book structure and summary of the chapters.

\section{THE EMERGENCE OF COLLABORATION}

The collaborative approach to planning, management and governance has a deep history in political science, public administration, planning, sociology, resilience theory and natural resources management. The concept has evolved from a range of concepts and ideas related to public participation, conflict resolution, democratic governance and increasingly complex problems that belied traditional solutions (Arnstein, 1969; Gildea, 1959; Godschalk and Mills, 1966; Lindblom, 1965; Litwak and Hylton, 1962; March and Simon, 1958).

However, as updated concepts of public roles, stakeholder involvement, networked governance, ecosystem management, conflict resolution and consensus-based processes took hold in the 1980s and 1990s, collaboration became increasingly touted as a new and emerging paradigm (Agranoff, 1990; Gray, 1989; Grumbine, 1994; Innes, 1995; Johnson and Agee, 1988; Rainey and Milward, 1983). In describing the emergence of collaboration, we cast a wide net over a range of literature. In the environmental field, integrated environmental management, watershed management and ecosystem management all incorporated many of the core elements of collaboration (Cortner and Moote, 1999; Loh and Rykiel, 1992; U.S. EPA, 1992). In public administration, collaboration is related to inter-organizational coordination and networks, which has been a growing theme in how governments and organizations work more effectively together to solve complex problems (Agranoff, 1990; Knoke, 1990; O’Toole, 1990; Rainey 
and Milward, 1983). Finally, in planning and public policy, collaboration, consensus building and collaborative planning were all used to describe this emerging approach (Healey, 1992; Innes and Booher, 1999; Susskind and Cruikshank, 1987).

Just as important to the emergence of collaboration as a theoretical concept was the increasing use of collaboration in practice. Through necessity imposed by problem complexity, conflict, interjurisdictional interaction or simply pressure for results, practitioners began experimenting with strategies and approaches that researchers eventually coined "collaborative governance" (Born and Genskow, 1999; Born and Margerum, 1993; Curtis, 1998; NPCC, 2006; Robinson et al., 2014; Ross et al., 2009; U.S. EPA, 1992). This on-the-ground experimentation quickly provided findings about effective practice that helped test existing theory and build new theory.

As several authors in this volume point out, the research on collaboration has shifted over the years from presenting the normative claims of collaboration, to defining best practices, to developing typologies and frameworks (Margerum, Chapter 2; Koontz, Chapter 3; Agranoff, Chapter 4). A significant literature has emerged on the capacity and possibilities of collaboration but note that mechanisms to build consensus and paradigms under which collaborative governance are institutionalized can marginalize some stakeholders, ignore different types of knowledge throughout the planning process and empower some perspectives over others (Gilfedder et al., Chapter 6; Nelson et al., Chapter 12; Robinson, Chapter 16).

The history of collaborative practice throughout the world could be a book by itself, but it is worthwhile to consider some context and examples of where these concepts have emerged. We focus on its development in the United States, Europe and beyond, but as several chapters in this book demonstrate, it's a concept being adopted in countries throughout the world.

\section{United States}

In the United States, concepts such as integrated environmental management, ecosystem management and watershed management were becoming increasingly applied in practice in the 1980s and 1990s (Born and Genskow, 2000; Born and Sonzogni, 1995; Cairns and Crawford, 1991; Cortner and Moote, 1999; Gardiner et al., 1994; Grumbine, 1994; Hooper, 1995; Mitchell and Pigram, 1989). These approaches were responding to complex problems that crossed multiple boundaries and generated difficult tensions and conflict. The heart of these concepts was the concept of collaborative interaction among a range of participants. 
In the area of water quality management, it was becoming increasingly apparent that goals could not be achieved without an approach that addressed both point and nonpoint sources (Born and Genskow, 2000; Dixon and Easter, 1986). The US Environmental Protection Agency (EPA) promoted a watershed approach that encouraged broad based stakeholder engagement due to the range of implementation actions, but particularly because many nonpoint source pollution goals required community and landowner participation (U.S. EPA, 1992).

In the management of water quantity and water flow, legal challenges to existing arrangements empowered environmentalists and other users. As the long-term effects of historical management practices became more apparent, these groups used policies such as the US Endangered Species Act to force agencies to reconsider policies and management approaches (Layzer, 2008; Margerum, 2011; Weber, 2000). These policies have been particularly powerful as environmental impact reviews and hydroelectric license renewals raise new issues not considered when projects were constructed 40-50 years ago. As a result, in places such as the Florida Everglades, Columbia Basin and San Francisco Bay Delta, these challenges have led to significant collaborative efforts and ongoing conflict about long-term management approaches (Benson et al., 2013; Dutterer and Margerum, 2015; Heikkila, 2006; Innes et al., 2007; Lurie, 2011).

In forestry and natural resources management, agencies such as the US Forest Service were increasingly facing ecological questions that challenged their traditional production approach (Koontz et al., 2004; Weber, 2003). The competing uses for public lands and increasing concern about endangered species led to legal challenges and conflict that stalled plans and timber projects (Thomas, 2003). Managers began experimenting with negotiated and collaborative strategies, while community-based efforts emerged to bring the range of perspectives together using more collaborative approaches (Carr et al., 1998; Moseley and KenCairn, 2001).

\section{Europe}

The emergence of collaborative governance in Europe has been influenced by a range of national and regional trends, including the increased role in public-private partnerships and new models promoting more interactive governance (Skelcher et al., 2013; Sørensen and Torfing, 2008; Sullivan and Skelcher, 2002; Wesseling, 2011). In the UK, the increased use of public-private partnerships spawned a wide range of collaborative efforts across government sectors (Vangen et al., 2014) which prompted scholars to examine the various interactive and adaptive dimensions of collaborative planning regimes (e.g. Healey, 1997; Prager et al., 2012; Van Buuren, 
2009). Across Europe, reductions in the size of government and an increased focus on performance has resulted in governance more focused on effectiveness and efficiency (Voets et al., 2008). With the increasing recognition that problems span organizational boundaries, there has been increasing attention on the performance across the network of collaborating organizations (Arnouts et al., 2012; Voets et al., 2008). Resilience thinking has also considered how the design of collaborative governance systems can enhance system attributes for resilience in different planning contexts (e.g. natural resource management) and for different planning purposes (e.g. Olsson et al., 2004; Wilkinson, 2012).

One important recent influence on environmental governance has been the European Union's Water Directive Framework and Common Implementation Strategy, which has promoted a river basin approach and a more participatory planning model (Moss, 2012; Newig and Koontz, 2014; Wesseling, 2011). This has led to a range of approaches ranging from agency-led basin initiatives in England and Wales, river basin agency-led efforts in France and the Netherlands, and a more collaborative structure in Germany (Moss, 2012; Newig and Koontz, 2014; Warner, 2007). Each country has faced its own set of implementation challenges, including complications from multi-level implementation, distrust of public agencies with less participatory traditions, and the complications of international boundaries (Bréthaut and Pflieger, 2013; Newig and Koontz, 2014; Warner, 2007).

\section{And Beyond}

The experiment with collaboration has also been tried in a number of countries in a wide range of cultural, institutional and economic contexts, including Australia, New Zealand, Canada, South America and Southeast Asia (Curtis et al., 2014; Robinson et al., 2011; Taylor and de Loe, 2012; Warner, 2007). While much of this scholarship reinforces European and North American traditions, researchers have also added to this scholarship based on lessons learned from the context of collaborative practice. This includes the role of collaboration to reconcile the relationships between Indigenous peoples and Europeans, including rights to territory, its uses and derived resources (e.g. Hill et al., 2012; Lane and Hibbard, 2005; Maclean et al., 2015; Robinson and Lane, 2013; Ross et al., 2009). Intellectual frameworks from planning, geography, resilience, sociology, public policy and economics have also been used to critically examine national and regional policy attempts to refashion collaborative governance as a means of reinvigorating democracy, improving the fidelity and efficacy of government and achieving diverse and complex environmental 
policy goals (e.g. Lane et al., 2009). This includes modifications of collaborative approaches to resolve complex water quality and resource sharing issues (e.g. Kroon et al., 2009; Robinson et al., 2014) including comparative case-study analysis with Northern Hemisphere experiences (e.g. Margerum and Robinson, 2014). Theoretical approaches from geography, resilience theory and planning have also explored collaborative approaches to conservation planning and practice (Armitage et al., 2012; Hill et al., 2015). Sub-disciplines from ecology have also added to the debate by highlighting the potential and challenges of collaborative approaches to natural resource management including forestry and fisheries (e.g. Maclean et al., 2015; Pinkerton, 1989).

\section{DEFINING THE THEMES OF THIS BOOK}

As highlighted above there are many excellent publications on multiple facets of collaborative governance. Our goal in this book is not to provide an overview of the collaboration concept, but to explore key challenges as the theory and practice of collaboration matures. Therefore, this book is focused around three themes reflected in the title: collaboration, challenges and governance.

\section{Collaboration}

Collaboration has rapidly evolved from an emerging concept to common practice and a dominant theme in the governance literature. The concept of working across boundaries, a regional focus and public consultation have all been long-standing themes in governance (Advisory Commission on Interstate Relations, 1972; Arnstein, 1969; Dworsky and Allee, 1981; Healey, 1997; Rogers and Whetten, 1982). More recently these concepts were updated to reflect the need to examine problems in a more holistic and integrated approach through terminology such as co-management, integrated management, and watershed and ecosystem management (Berkes, 2009; Born and Sonzogni, 1995; Cortner and Moote, 1999; Johnson and Agee, 1988; Loh and Rykiel, 1992; Margerum, 1999). Collaboration is broad and diverse drawing from multiple academic lenses to examine how real-world collaborative arrangements and practice achieve inclusive participation, consensus-based approaches, knowledge sharing, integrated management and supporting networks (Gray, 1989; Innes and Booher, 2009; Margerum, 2011; Robinson et al., 2011). Concepts surrounding co-management, networks and inter-organizational collaboration are often used interchangeably to describe consensus-based approaches to 
managing cross-boundary problems through formal and informal structures (Agranoff, 2007; Goldsmith and Eggers, 2004; Mandell, 1990; McAllister et al., 2015; Provan and Milward, 1995).

Collaboration is broadly defined as a consensus-based approach to management and governance involving a wide range of stakeholders in an ongoing role. However, it is not limited to government-initiated or government-led efforts. As researchers note, consensus is often an ongoing and political process that can engage, disengage, contain or even block certain stakeholders. There are now examples of communitybased collaboration efforts that have mobilized local stakeholders yet can have limited roles for government, collaborations where non-government organizations play a central convening and facilitation role, and consensusbuilding efforts that are targeted for particular environmental management outcomes and/or stakeholder groups (Gray, 1989; Linden, 2002; Warner, 2007; Weber, 2000). Common to all these manifestations of collaboration is that power is shared so that collaborators can agree on solutions to share responsibility for common and often complex environmental issues.

Some collaborative efforts have emerged to promote voluntary action, such as motivating landowners to adopt conservation actions to improve water quality or habitat (Robinson et al., 2014). However, there are many examples of collaborative efforts that have emerged without top-down authority, such as collaborative efforts to manage air quality and metropolitan growth (Barbour and Teitz, 2009; Margerum, 2005). It could be argued that some of these collaboration efforts have effectively expanded the role of government where state or regional governance was not willing to address these issues. There are also examples of collaborative efforts that have led to new policy, different policy interpretations or new management programs (Margerum, 2007; Robinson et al., 2011). In many cases, there are collaborative efforts to developing policy or management plans, but implementation follows traditional hierarchical approaches.

These different views of collaboration are often distinguished by differences in the focus of collaboration. In some cases, the collaboration operates at the highest levels of governance. In these settings, the topics of collaboration are the policies themselves and how policies and programs should be implemented. These policy-level collaboration efforts often involve elected officials, policy stakeholders and interest groups that work at this policy level (Lurie, 2011; Margerum, 2011; McAllister et al., 2015; Robinson et al., 2011). For example, much of the collaboration efforts in the Sacramento-San Joaquin Delta case study, commonly referred to as CALFED (Wondolleck and Lurie, Chapter 9), have involved deliberation about state and federal water quality and quantity — and the programs and activities to achieve collective goals. 
In contrast, some efforts occur within the existing policies, and collaboration is more focused on the integration of governance among the array of government and non-government organizations. These organizational-level collaboration efforts involve individuals representing organizations as well as other stakeholders that may contribute important perspectives (Imperial, 2005; Margerum, 2011). For example, Thomas (2003) examines the roles of agencies such as the National Park Service and Bureau of Land Management in coordinating the management of public lands for biodiversity.

Finally, some collaboration efforts are focused more on direct actions, such as restoration and best management practices. These action-level collaboration efforts tend to be community-based or grass-roots-level efforts that involve an array of individuals who can help promote collective actions and community support (Curtis and Lockwood, 2000; Margerum, 2011). These efforts may also involve government participants, but they tend to be involved as technical advisors or program funders. As a result these efforts are less likely to involve the sharing of power by organizational participants, because the focus is more upon on-the-ground delivery. Some of these efforts may also be led and carried out without government involvement (Koontz et al., 2004).

Clearly, collaboration activities don't always fit neatly into this policyorganizational-action typology. There are many examples of efforts that span these categories, shift focus over time or present nested approaches. However, it is important to carefully define the topic that is the focus of collaboration so that there is a logical comparison of findings across different contexts. Using research and examples from around the world along with theories from a range of disciplines this book proposes to explore the challenges of collaboration. Challenges are defined in terms of the structural, procedural and substantive aspects of collaborative governance. These limitations may be barriers that cannot be overcome; they may be the boundaries of collaboration effectiveness; in some cases they may be able to overcome with innovative strategies and responses.

\section{Challenges}

Challenges with respect to collaboration can be described as limitations, weaknesses or difficulties which affect the efficacy of consensus building efforts to negotiate and deliver agreed goals. There is a range of ways in which these challenges have been examined.

First, some challenges relate to the limitations of collaborative governance in the face of deep-seated conflict, culture or power barriers (Hill et al., 2012; Leach and Pelkey, 2001). For example, several researchers note the difficulty of applying collaborative management in developing 
countries with authoritarian governments and deep-seated regional animosities (Dore, 2007; Wegerich, 2007) or in cross-cultural contexts where democratic approaches to stakeholder engagement and building consensus is not appropriate (Robinson and Wallington, 2012). It is also important to note that these are also limitations of traditional governance approaches.

Second, there are challenges that can be classified as weaknesses of the collaboration model. These are the vulnerable points where failure is more likely to occur. There are examples of how these weaknesses can be overcome, but they are often not occurring in practice because they are difficult or complex. For example, collaborative efforts that rely heavily on stakeholder perspectives are sometimes criticized for failing to include a diversity of views and perspectives (Healey, 1997; Leach, 2006; Purdy, 2012; Sousa and Klyza, 2007). Participants are more likely to include organized interests, and those with the education, time and resources to participate (Kroon et al., 2009; Leach, 2006). There are examples of strategies for overcoming these representation weaknesses, but they involve additional time and resources, and different strategies to reach a more diverse set of voices (see Rongerude and Sandoval, Chapter 14).

Third, some challenges relate to the difficulties of applying the collaborative model. These are the components of the design that shouldn't fail if people are paying attention to how it is operating. It may require training, experience and careful attention to best practices. For example, much has been written about the issue of collaborative leaders, brokers and facilitators (Edelenbos et al., 2013; Lejano and Ingram, 2010). There are many accounts of the key principles, strategies and innovative examples of practice (Chrislip and Larson, 1994; Crosby and Bryson, 2010; Linden, 2008). However, these roles can be difficult and delicate (see Forester, Chapter 15). Mistakes and poor practice can unravel good sound principles.

It is important to acknowledge that all of the challenges outlined in this book also appear in other forms of governance - including hierarchical, non-consultative approaches. For example, authoritarian governance, representation diversity and leadership are challenges for governance generally. However, these issues have also been scrutinized by researchers over the years. If collaborative governance is to be promoted as an alternative to traditional decision making, it must be able to undergo the same level of assessment. It is only through this scrutiny that the theory and practice of collaboration will improve.

\section{Governance}

The final term that comprises a major theme in this book is governance, which has a wide range of definitions. Environmental planning and 
decision making in many countries around the world has undergone a fundamental shift in which actors from civil society and the market are participating more directly in environmental policy formation and implementation. There are now different governance regimes that exist around the world each of which provide various institutional mechanisms for sectors of society to engage in environmental decisions through formal and informal structures (Provan and Kenis, 2008; Vangen et al., 2014). These terms are often associated with networks, which emphasizes horizontal relationships in contrast to more traditional, hierarchical relationships (Arnouts et al., 2012; Lange et al., 2013; Provan and Kenis, 2008; Vangen et al., 2014). One of the debates appearing in the public administration and planning literature is whether there is a shift from government to governance, or whether the change is towards new governance that reflects increased interdependencies (Lange et al., 2013; Lindquist, 2004). These increased interdependencies include increased participation of non-state actors that supplement bureaucratic authority rather than replace it (Head, 2008; Lange et al., 2013).

While some confine the definition of governance to those initiated or sanctioned by formal government (Ansell and Gash, 2007), many view governance more broadly to include a range of decision makers (Emerson et al., 2012). This may include community-based or self-determined approaches to governance, which may occur without formal government roles (Arnouts et al., 2012; Kooiman, 2003). However, one of the common defining characteristics of governance is collective action (Ansell and Gash, 2007), which requires key participants to interact on an ongoing basis through formal and informal networks (Emerson et al., 2012).

By using the term governance, we recognize the various types of consensus-based efforts. Some of the literature on collaborative planning and conflict resolution views collaborative processes in terms of reaching an agreement, completing a contract or finalizing a plan. This approach implies a more cooperative approach in which negotiated plans and agreements are the primary guide for future decision making. Collaborative governance implies that stakeholders play an ongoing role in decision making in which there is a need for coordination of management and adjustment in response to new information and changing conditions (Agranoff, 2007; Bingham and O’Leary, 2008).

\section{OVERVIEW OF CHAPTERS}

The chapters in this book offer contributions from a range of disciplines and contexts. Our goal in seeking out leading authors in this field is to 
identify those who have been exploring the cutting edge of conceptual thinking and empirical research. We also sought authors working across the world to allow a shared comparison of trends and differences. The book is divided into six sections addressing:

1. Theory and context

2. Problems and context

3. Policy, politics and power

4. Organizations, stakeholders and governance

5. Process and participation

6. Conclusions.

\section{Theory and Context}

Chapter 2 by Richard D. Margerum reviews the literature from areas such as collaboration, consensus building, conflict resolution and network theory to examine some of the underlying themes about the challenges of collaboration. The goal of this chapter is not to confirm or deny these challenges, but to document the range of researchers who have raised collaboration challenges as a significant issue and organize them into themes. The challenges are grouped into the following themes: (a) problems and societal context; (b) policy and political setting; (c) power; (d) collaborative ability and capacity; (e) participant factors; and (f) costs and benefits. In reviewing these themes, he also seeks to identify the theoretical underpinnings of these challenges to help guide future research.

Tomas M. Koontz draws on the American context to review the evolution of collaboration in environmental governance over time in Chapter 3. He examines the origins of ecosystem management, its focus on a holistic, interdisciplinary approach and its gradual expansion to address social concerns and stakeholder and organizational roles. He also traces the early origins in community-based, collaborative environmental management. With origins in Elinor Ostrom's work on self-governance in response to the failures of centralized government control, collaborative partnerships emerged to fill important gaps and voids. The early scholarship in this realm focused on the failures of top-down practice and best practices and the second generation scholarship began to propose typologies, models, and to take a more critical examination of outcomes. Finally, he examines the research on collaborative public management in response to reduced government roles, resulting in more networked forms of governance. His comparison of these fields and their evolution over time reveals some important common themes and differences, and the tensions between theory and practice. 
In Chapter 4, Robert Agranoff examines the limitations of networks as a form of collaborative management by looking deeper into issues related to their internal operational processes. First, he highlights the complexities involved when agencies and organizations work collaboratively including challenges of governing bodies, statutory constraints, turf battles and the management of network processes. Second, he highlights the overlooked issue of mission incompatibility and the challenges it creates in working collaboratively. Third, there is the issue of "big P" politics; or the role of elective leaders in supporting or constraining collaborative efforts. Fourth, there are the "small p" politics of process, power and operational barriers in the collaboration process. Fifth, there is the array of processing barriers or transaction costs. Sixth, he notes the issue of process fatigue created by the complexity of multiple collaboration efforts. Finally, there are the perils of operational localism, or the gap between policy and delivery. Agranoff suggests that these limitations can be more effectively addressed by applying continuous improvement functions that suggest more systematic approaches to improving collaborative practice.

In Chapter 5, Jurian Edelenbos and Ingmar van Meerkerk introduce the phrase "vitality mechanisms" which support interactive and collaborative governance and discuss the challenges associated with applying them in practice. Vitality mechanisms refer to the procedural and relational capacity among actors in a network, which they suggest is strongly related to governance capacity and relational capacity. Vitality is supported by informal structures or settings that promote interaction among actors, boundary spanning activities that build and activate relationships among actors, constructive dialogue and deliberation among actors, trust to enhance the performance of networks, and institutionalization of relationships that allow ongoing interaction. However, these conditions necessary for supporting vitality also confront challenges related to the interplay between the conditions, the impacts of the evolution of networks over time, and the contextual effects on these conditions.

\section{Problems and Context}

In Chapter 6, Mat Gilfedder, Cathy J. Robinson and Mike Grundy critically evaluate how scientific evidence is used to guide and evaluate collaboration. Drawing on expertise in collaborative planning, hydrology and soil systems science, they trace the challenges in Australia of translating scientific data into informed and sustained on-ground, voluntary responses. They highlight the challenges of introducing complex and uncertain scientific information into real-world collaborative decisions and on-ground actions. The chapter also highlights the importance of considering and 
debating science at the collaborative planning table, even if the information challenges fluctuating support for long-term, on-ground efforts to address broad and undesirable environmental change.

In Chapter 7, Arwin van Buuren and Jitske van Popering-Verkerk address the challenges of utilizing collaboration to address one of the most challenging issues facing society today - climate change adaptation. Drawing on an analysis of Dutch efforts to manage their Delta Programme, they found that consensus efforts were able to overcome deep uncertainties and value controversies. However, they also found significant challenges, including the need to develop more powerful political leadership, tradeoffs between scientific depth and negotiated knowledge and trade-offs between consensus and decisiveness. They conclude that the approach in the Dutch Delta Programme has been successful in introducing new ways of working, but can't determine whether this has been sufficient to adjust standard routines in the water domain.

In Chapter 8, Helen Ross, Jennifer Bellamy and Brian Head examine the challenges of using collaboration on a regional scale to address wicked problems in Australia. Their research examines four diverse collaborative efforts: salinity management in an important irrigated agricultural region, dryland salinity in a landscape with high biodiversity values, water quantity management in inland Australia, and water quality in the urbanized South East Queensland region. Their comparative work reveals five consistent challenges. First, the complexity and difficulty associated with solving the problems creates significant resistance that requires major problems or crises to develop political will. Second, building and maintaining collaborative arrangements with continuous policy adjustments and changing stakeholders has generated a constantly adapting governance environment. Third, a diverse range of collaborative scientific research of unique relevance to each region may be available, but needs to be well linked with local knowledge systems and management needs in order to gain acceptance. Fourth, there has been a mismatch between political and policy time frames and the timescales needed to address long-term resource decision making. Finally, there has been the difficulty of managing in a multi-level context; ranging from national- and state-level policy to community engagement and local participation.

\section{Policy, Politics and Power}

In Chapter 9, Julia M. Wondolleck and Susan D. Lurie examine the issue of mandated collaboration, which contradicts the long-standing central tenet of voluntary participation that emerged from the field of alternative dispute resolution. They examine this issue using thorough research on 
the CALFED case. They note that collaboration was essentially mandated through instilling a sense of urgency, developing a need to work together through procedural and political means, developing the recognition that the CALFED approach was the preferred alternative, and creating procedures that ensured greater fairness. However, they identify three significant process challenges that weakened this mandated approach: faltering political support that undermined the mandate, resistance within the agencies among those not directly involved, and the difficulty of shared accountability.

In Chapter 10, Edward P. Weber examines the issue of political support for collaborative governance and the logic of support that spans both liberal and conservative politicians in the western United States. For liberal politicians, collaborative governance is viewed as a way to achieve environmental goals such as species recovery. From their perspective, the national environmental superstructure of environmental laws provides enough security that their preferred environmental protection outcomes will be reached that they are willing to loosen the reins of discretion in order to produce better outcomes. For conservative politicians, the place-based collaboration approach matches the conservative ideas of small government and governance close to home. This support continues to be challenged by lawsuits from the left and right, but broad-based public interest outcomes offer policy solutions that are often hard for elected officials to oppose. In response to these trends, Weber notes that politicians have been granting more discretion to agencies, which also have been lending more support to collaboration due to declining budgets and more emphasis on collaboration.

Jill M. Purdy examines the issue of power in collaborative governance in Chapter 11. She notes that the use of episodic power in everyday interactions is more easily managed than structural power, which is rooted in the institutional order of society and is often invisible. She discusses forms of power, orientations toward power, and power dynamics stemming from the desire for legitimacy within one's institutional order. She identifies two challenges for managing power in environmental collaborations. First, the context for interaction may not insulate participants from the demands of their institutional logics, preventing the creation of a shared logic that allows a robust and equitable process. Second, the legitimacy of collaboration as a governance system may be insufficient, particularly when collaborations may identify solutions that challenge the basis and order of the inter-institutional system. She concludes that power issues may impose barriers on the meaningful participation of diverse groups in environmental decision making and planning that are difficult to overcome. 


\section{Organizations, Stakeholders and Governance}

In Chapter 12, Daniel H. Nelson, Rosemary O'Leary, Larry D. Schroeder, Misty Grayer and Nidhi Vij examine the adoption and challenges of using collaboration in the Indian Forest Service. Their findings revealed surprisingly high rates of collaboration support and use within the agency, and participants were strongly motivated by leveraging resources, common purpose and improving outcomes. The challenges of collaborating in India include hierarchical structure, misalignment of interests, different organization cultures, clashing time horizons, numerous stakeholders, low accountability, complex political environments, frequent transfers of personnel, low trust and lack of transparency. The authors present a new three-part Need-Attitude-Skillset theory of collaboration.

Jeroen F. Warner, Jan M. Fliervoet and Antoine J. M. Smits examine the challenges facing the Netherlands' approach to collaborative governance in Chapter 13. They compare three case studies of mono- or multi-functional floodplain maintenance, to assess the scope for a Joint Maintenance Approach (JMA) in a Dutch context in light of the actor configuration, changing role of the public sector in land-use planning and the fragmented maintenance activities. Exploring JMA revealed several collaborative challenges. An important challenge is how to sustain multistakeholder collaboration established in the planning and implementation phase. Additionally, there are complications related to multi-stakeholder leadership, conflicting policies and fragmentation of powers within organizations. Finally, the Dutch experience highlights challenges in integrating public and non-governmental roles in land-use planning.

\section{Process and Participation}

In Chapter 14, Jane Rongerude and Gerardo Francisco Sandoval examine the issue of participation through the lens of an intensive, grass-roots engagement strategy. Through direct experimentation, they have been able to demonstrate and refine techniques for engaging some of the least powerful and most marginalized communities. Their approach seeks to address the long-standing weakness of collaboration that relates to stakeholder-based processes. However, they also identify significant challenges to this approach that relate to the difficulty of creating an ongoing role for marginalized communities, the costs and time involved in undertaking this approach, and the difficulty of finding third parties who can take the lead role in implementing the outreach approach.

In Chapter 15, John Forester explores the challenges of facilitators' roles in collaborative processes and the ways that researchers can learn from 
such facilitators' experiences. By examining a rich practice story detailing a facilitator's collaborative work, the chapter focuses upon facilitators' professional expertise, their concerns about inefficiency and the complexities of convening, guiding and intervening. Forester also highlights the challenges for researchers to define and explain collaborative approaches, which often do not fit traditional labels of facilitation, collaboration or dispute resolution. He challenges researchers to do a better job of exploring grounded accounts of collaborative work by practitioners to help readers better understand the complexities of collaborative efforts. Forester argues that researchers and practitioners alike must think carefully about the challenges of building relationships, framing contentious issues, responding to participants' demands, and understanding the processes of dialogue, debate and negotiation - along with the corresponding intervening roles that each of these three processes require.

In Chapter 16, Cathy J. Robinson reviews the context for Indigenous collaborative partnerships in Australia. She highlights the history of disempowerment through Australian colonization, and the emerging collaborative management efforts evolving in the Northern Territory. These joint efforts have exposed several challenges, including tensions between wildlife conservation goals and Indigenous hunting that is important for both culture and subsistence, and the tensions between traditional environmental knowledge and scientific knowledge. These challenges along with the concepts of nature and culture that underpinned Northern Australian settlement have challenged contemporary cross-cultural collaborative efforts.

\section{Conclusions}

In Chapter 17, Richard D. Margerum, Cathy J. Robinson and Ken Genskow summarize some of the major issues confronting collaborative governance across the authors of this book. Using a peer-review process involving the book authors and other researchers examining collaboration, they also present a research agenda for collaboration. This agenda highlights the need for more longitudinal research, studies of politics and governance, work that addresses the art and nuance of collaborative processes, studies of the role of community and the public, research on the role of individual participants, studies examining science and problem complexity, research on the role of external pressures, and work that addresses issues of management relationships. 


\section{REFERENCES}

Advisory Commission on Interstate Relations. (1972). Multistate Regionalism. Washington, D.C.: U.S. Government Printing Office.

Agranoff, R. (1990). Responding to human crises: intergovernmental policy networks. In R. W. Gage and M. P. Mandell (eds.), Strategies for managing intergovernmental policies and networks. New York: Praeger.

Agranoff, R. (2007). Managing within networks: adding value to public organizations. Washington, D.C.: Georgetown University Press. Retrieved from http:// www.loc.gov/catdir/toc/ecip071/2006031171.html.

Ansell, C. and Gash, A. (2007). Collaborative governance in theory and practice. Journal of Public Administration Research and Theory, 18(4), 543-571.

Armitage, D., de Loë, R. and Plummer, R. (2012). Environmental governance and its implications for conservation practice. Conservation Letters, 5, 245-255.

Arnouts, R., van der Zouwen, M. and Arts, B. (2012). Analysing governance modes and shifts - governance arrangements in Dutch nature policy. Forest Policy and Economics, 16, 43-50. http://doi.org/10.1016/j.forpol.2011.04.001.

Arnstein, S. R. (1969). A ladder of citizen participation. Journal of the American Institute of Planners, 35(4), 216-224.

Barbour, E. and Teitz, M. B. (2009). Blueprint planning in California: an experiment in regional planning for sustainable development. In D. A. Mazmanian and M. E. Kraft (eds.), Toward sustainable communities: transition and transformations in environmental policy (2nd edn., pp. 171-200). Cambridge, MA: The MIT Press.

Benson, D., Jordan, A., Cook, H. and Smith, L. (2013). Collaborative environmental governance: are watershed partnerships swimming or are they sinking? Land Use Policy, 30, 748-757.

Berkes, F. (2009). Evolution of co-management: role of knowledge generation, bridging organizations and social learning. Journal of Environmental Management, 90, 1692-1702.

Bingham, L. and O'Leary, R. (eds.). (2008). Big ideas in collaborative public management. Armonk, N.Y.: M. E. Sharpe.

Born, S. M. and Genskow, K. D. (1999). Exploring the "watershed approach" critical dimensions of state-local partnerships. Madison, WI: University of Wisconsin Extension, Report No. 99-1.

Born, S. M. and Genskow, K. D. (2000). The watershed approach: an empirical assessment of innovation in environmental management (p. 70). Washington, D.C.: National Academy of Public Administration.

Born, S. M. and Margerum, R. D. (1993). Integrated environmental management: improving the practice in Wisconsin. Madison, WI: Wisconsin Department of Natural Resources.

Born, S. M. and Sonzogni, W. (1995). Towards integrated environmental management: strengthening the conceptualization. Environmental Management, 19(2), 167-183.

Bréthaut, C. and Pflieger, G. (2013). The shifting territorialities of the Rhone River's transboundary governance: a historical analysis of the evolution of the functions, uses and spatiality of river basin governance. Regional Environmental Change, 15(3), 549-558.

Cairns, J., Jr. and Crawford, T. V. (eds.). (1991). Integrated Environmental Management. Chelsea, MI: Lewis Publishers. 
Carr, D. S., Selin, S. W. and Schuett, M. A. (1998). Managing public forests: understanding the role of collaborative planning. Environmental Management, 22(5), 767-776.

Chrislip, D. D. and Larson, C. E. (1994). Collaborative leadership: how citizens and civic leaders can make a difference. San Francisco, CA: Jossey-Bass Publishers.

Cortner, H. J. and Moote, M. A. (1999). The politics of ecosystem management. Washington, D.C.: Island Press.

Crosby, B. C. and Bryson, J. M. (2010). Integrative leadership and the creation and maintenance of cross-sector collaborations. The Leadership Quarterly, 21(2), 211-230.

Curtis, A. (1998). Agency-community partnerships in landcare: lessons for statesponsored resource management. Environmental Management, 22(4), 563-574.

Curtis, A. and Lockwood, M. (2000). Landcare and catchment management in Australia: lessons for state-sponsored community participation. Society \& Natural Resources, 13(1), 61-73.

Curtis, A., Ross, H., Marshall, G. R., Baldwin, C., Cavaye, J., Freeman, C., Carr, A. and Syme, G. (2014). The great experiment with devolved NRM governance: lessons from community engagement in Australia and New Zealand since the 1980s. Australasian Journal of Environmental Management, 21(2), 175-199.

Dixon, J. A. and Easter, K. W. (1986). Integrated watershed management: an approach to resource management. In K. W. Easton, J. Dixon and M. M. Hufschmidt (eds.), Watershed resources management: an integrated framework with studies from Asia and the Pacific (pp. 3-16). Honolulu, HI: Westview Press, East-West Center.

Dore, J. (2007). Mekong region water-related MSPs-unfilled potential. In J. Warner (ed.), Multi-stakeholder platforms for integrated water management (pp. 205234). Aldershot, England: Ashgate.

Dutterer, A. D. and Margerum, R. D. (2015). The limitations of policy-level collaboration: a meta-analysis of CALFED. Society and Natural Resources, 28(1). http://doi.org/10.1080/08941920.2014.945054.

Dworsky, L. B. and Allee, D. J. (1981). Unified/integrated river basin management: evolution of organizational arrangements. In D. J. Allee, L. B. Dworsky and R. M. North (eds.), Unified river basin management, symposium proceedings. Minneapolis, MN: American Water Resources Association.

Echeverria, J. D. (2001). No success like failure: the Platte River collaborative watershed planning process. William and Mary Environmental Law and Policy Review, 25(3), 559-604.

Edelenbos, J., Bressers, N. and Scholten, P. (eds.). (2013). Water governance as connective capacity. Aldershot, England: Ashgate.

Emerson, K., Nabatchi, T. and Balogh, S. (2012). An integrative framework for collaborative governance. Journal of Public Administration Research and Theory, 22(1), 1-29.

Gardiner, J., Thomson, K. and Newson, M. (1994). Integrated watershed/river catchment planning and management: a comparison of selected Canadian and United Kingdom experiences. Journal of Environmental Planning and Management, 37(1), 53-67.

Gildea, R. J. (1959). Watershed management: past and present. The Journal of Geography, 58(1), 14-20.

Godschalk, D. R. and Mills, W. E. (1966). A collaborative approach to planning 
through urban activities. Journal of the American Institute of Planners, 32(2), $86-95$.

Goldsmith, S. and Eggers, W. D. (2004). Governing by network: the new shape of the public sector. Washington, D.C.: Brookings Institution Press. Retrieved from http://www.loc.gov/catdir/toc/ecip0421/2004019411.html.

Gray, B. (1989). Collaborating: finding common ground for multiparty problems. San Francisco, CA: Jossey-Bass, Inc.

Grumbine, R. E. (1994). What is ecosystem management? Conservation Biology, $8(1), 27-38$.

Hanemann, M. and Dyckman, C. (2009). The San Francisco Bay-Delta: a failure in decision making capacity. Environmental Science and Policy, 12(6), 710-725.

Head, B. W. (2008). Assessing network-based collaborations: effectiveness for whom? Public Management Review, 10(6), 733-749.

Healey, P. (1992). Planning through debate: the communicative turn in planning theory. Town Planning Review, 63(2), 143-162.

Healey, P. (1997). Collaborative planning. Vancouver, Canada: University of British Columbia Press.

Heikkila, T. (2006). Comparing collaborative mechanisms in large-scale ecosystem governance. Natural Resources Journal, 46(3), 51.

Hill, R., Grant, C., George, M., Robinson, C. J., Jackson, S. and Abel, N. (2012). A typology of Indigenous engagement in Australian environmental management: implications for knowledge integration and social-ecological system sustainability. Ecology and Society, 17(1), 23.

Hill, R., Davies, J., Bohnet, I., Robinson, C. J., Maclean, K. and Pert, P. L. (2015) (on line). Collaboration mobilises institutions with scale-dependent comparative advantage in landscape-scale biodiversity conservation. Environmental Science \& Policy, 51, 267-277.

Hooper, B. (1995). Integrated resource management - a national vision for Australia. Australian Journal of Soil and Water Conservation, 8(1), 9-12.

Imperial, M. T. (2005). Lessons from six watershed management programs. Administration \& Society, 37(3), 281-320.

Innes, J. E. (1995). Planning theory's emerging paradigm: communicative action and interactive practice. Journal of Planning Education and Research, 14(3), 183-189. http://doi.org/10.1177/0739456X9501400307.

Innes, J. E. and Booher, D. E. (1999). Consensus building and complex adaptive systems: a framework for evaluating collaborative planning. Journal of the American Planning Association, 65(4), 412-423.

Innes, J. E. and Booher, D. E. (2009). Planning with complexity: an introduction to collaborative rationality for public policy. New York: Routledge.

Innes, J. E., Connick, S. and Booher, D. (2007). Informality as a planning strategyCollaborative water management in the CALFED Bay-Delta Program. Journal of the American Planning Association, 73(2), 195-210.

Johnson, D. R. and Agee, J. K. (1988). Introduction to Ecosystem Management. In J. K. Agee and D. R. Johnson (eds.), Ecosystem management for parks and wilderness. Seattle, WA: University of Washington Press.

Knoke, D. (1990). Political networks: the structural perspective. Cambridge, England and New York: Cambridge University Press.

Kooiman, J. (2003). Governing as governance. London: Sage Publications.

Koontz, T. M., Steelman, T. A., Carmin, J., Korfmacher, K. S., Moseley, C. and Thomas, C. W. (2004). Collaborative environmental management: what roles for 
government? Washington, D.C.: Resources for the Future. Retrieved from http:// www.loc.gov/catdir/toc/ecip0419/2004014207.html.

Kroon, F. J., Robinson, C. J. and Dale, A. P. (2009). Integrating knowledge to inform water quality planning in the Tully-Murray Basin, Australia. Marine \& Freshwater Research, 60(11), 1183-1188.

Lane, M. B. and Hibbard, M. (2005). Doing it for themselves. Transformative planning by Indigenous peoples. Journal of Planning Education and Research, 25(2), $172-184$.

Lane, M. B., Robinson, C. J. and Taylor, B. (eds.). (2009). Contested country: local and regional environmental management in Australia. Melbourne: CSIRO Publishing.

Lange, P., Driessen, P. P. J., Sauer, A., Bornemann, B. and Burger, P. (2013). Governing towards sustainability - conceptualizing modes of governance. Journal of Environmental Policy \& Planning, 15(3), 403-425. http://doi.org/10.10 80/1523908X.2013.769414.

Layzer, J. A. (2008). Natural experiments: ecosystem-based management and the environment. Cambridge, MA: The MIT Press.

Leach, W. D. (2006). Collaborative public management and democracy: evidence from western watershed partnerships. Public Administration Review, 66(s1), $100-110$.

Leach, W. D. and Pelkey, N. W. (2001). Making watershed partnerships work: a review of the empirical literature. Journal of Water Resources Planning and Management, 127(6), 378-385.

Lejano, R. P. and Ingram, H. (2010). Collaborative networks and new ways of knowing. Environmental Science and Policy, 12(6), 653-662.

Lindblom, C. E. (1965). The intelligence of democracy. New York: Free Press.

Linden, R. (2008). Collaborating across organizational boundaries. In T. Newell, G. Reeher and P. Ronayne (eds.), The trusted leader: building the relationships that make government work (pp. 156-180). Washington, D.C.: CQ Press.

Linden, R. M. (2002). Working across boundaries: making collaboration work in government and nonprofit organizations (1st edn.). San Francisco, CA: JosseyBass. Retrieved from http://www.loc.gov/catdir/toc/wiley031/2002011933.html.

Lindquist, E. (2004). Strategy, capacity and horizontal governance: perspectives from Australia and Canada. Optimum: Journal of Public Sector Management, 34(4), 2-12.

Litwak, E. and Hylton, L. F. (1962). Interorganizational analysis: a hypothesis on co-ordinating agencies. Administrative Science Quarterly, 6(March/April), 395-420.

Loh, D. K. and Rykiel, E. J., Jr. (1992). Integrated resource management systems: coupling expert systems with data-base management and geographic information systems. Environmental Management, 16(2), 167-177.

Lubell, M. (2004). Collaborative environmental institutions: all talk and no action. Journal of Policy Analysis and Management, 23(3), 549-573.

Lurie, S. D. (2011). The CALFED Bay-Delta Program: lessons from the rise and fall of a large-scale ecosystem management network. Journal of Natural Resources Policy Research, 3(3), 251-262.

Maclean, K., Robinson, C. J., Natcher, D. (2015). Consensus building or constructive conflict? Aboriginal discursive strategies to enhance participation in natural resource management in Australia and Canada. Society and Natural Resources, 28(2), 197-211. 
Mandell, M. P. (1990). Network management: strategic behavior in the public sector. In R. W. Gage and M. P. Mandell (eds.), Strategies for Managing Intergovernmental Policies and Networks. New York: Praeger.

March, J. G. and Simon, H. A. (1958). Organizations. New York: Wiley.

Margerum, R. D. (1999). Integrated environmental management: the elements critical to success. Environmental Management, 65(2), 181-192.

Margerum, R. D. (2005). Collaborative growth management in metropolitan Denver: "fig leaf or valiant effort?" Land Use Policy, 22(4), 373-386.

Margerum, R. D. (2007). Overcoming locally based collaboration constraints. Society \& Natural Resources, 20(2), 135-152.

Margerum, R. D. (2011). Beyond consensus: improving collaborative planning and management. Boston, MA: The MIT Press.

Margerum, R. D. and Robinson, C. J. (2014). Limitations of collaborative partnerships for sustainable water management. Current Opinion in Environmental Sustainability, 12, 53-58.

McAllister, R., Robinson, C. J., Maclean, K., Guerrero, A., Collins, K., Taylor, B. and De Barro, P. (2015). From local to central: a network analysis of who manages plant pest and disease outbreaks across scales. Ecology and Society, 20(1), 67.

Mitchell, B. and Pigram, J. J. (1989). Integrated resource management and the Hunter Valley conservation trust, NSW, Australia. Applied Geography, 9(3), 196-211.

Moseley, C. and KenCairn, B. (2001). Problem solving or social change? The Applegate and Grand Canyon forest partnerships. In R. K. Vance, C. B. Edminster, W. W. Covington and J. A. Blake (eds.), (Vol. proceedings RMRS-P-22, pp. 121-129). Ponderosa pine ecosystems restoration and conservation: steps toward stewardship, Ogden, Utah: Department of Agriculture, Forest Service.

Moss, T. (2012). Spatial fit, from panacea to practice: implementing the EU Water Framework Directive. Ecology and Society, 17(3), 2.

Newig, J. and Koontz, T. M. (2014). Multi-level governance, policy implementation and participation: the EU's mandated participatory planning approach to implementing environmental policy. Journal of European Public Policy, 21(2), 248-267. http://doi.org/10.1080/13501763.2013.834070

NPCC. (2006). Transportation collaboration in the States. (Report prepared by the National Policy Consensus Center for the Federal Highway Administration Office of Project Development and Environmental Review.) (p. 38). Portland, OR: National Policy Consensus Center.

Olsson, P., Folke, C. and Berkes, F. (2004). Adaptive co-management for building social-ecological resilience. Environmental Management, 34, 75-90.

O’Toole, L. J., Jr. (1990). Multiorganizational implementation: comparative analysis for wastewater treatment. In R. W. Gage and M. P. Mandell (eds.), Strategies for managing intergovernmental policies and networks (pp. 81-111). New York: Praeger.

Pinkerton, E. (ed.). (1989). Co-operative management of local fisheries: new directions for improvement management and community development. Vancouver: University of British Columbia Press.

Prager, K., Reed, M. and Scott, A. (2012). Encouraging collaboration for the provision of ecosystem services at a landscape scale - rethinking agri-environmental payments. Land Use Policy, 29, 244-249. 
Provan, K. G. and Kenis, P. (2008). Modes of network governance: structure, management and effectiveness. Journal of Public Administration Research and Theory, 18, 229-252.

Provan, K. G. and Milward, H. B. (1995). A preliminary theory of interorganizational network effectiveness: a comparative study of four community mental health systems. Administrative Science Quarterly, 40(1), 1-33. http://doi. org/10.2307/2393698.

Purdy, J. M. (2012). A framework for assessing power in collaborative governance processes. Public Administration Review, 72(3), 409-417. http://doi. org/10.1111/j.1540-6210.2011.02525.x.

Rainey, H. G. and Milward, H. B. (1983). Public organizations: policy networks and environments. Newbury Park, CA: Sage Publications.

Robinson, C. J. and Lane, M. B. (2013). Boundary riding Indigenous knowledge contributions for natural resource decision-making in Northern Australian regions. In B. Walker, T. Jojola and D. Natcher (eds.), Reclaiming Indigenous Approaches to Community and Land-use Planning in the Twenty-first Century (pp. 396-413). Montreal: McGill-Queen's University Press.

Robinson, C. J. and Wallington, T. J. (2012). Boundary work: engaging knowledge systems in co-management of feral animals on Indigenous lands. Ecology and Society, 17(2), 16.

Robinson, C., Margerum, R., Koontz, T., Moseley, C. and Lurie, S. (2011). Policy-level collaboratives for environmental management at the regional scale: lessons and challenges from Australia and the United States. Society \& Natural Resources, 24(8), 849-859.

Robinson, C. J., Taylor, B., Vella, K. and Wallington, T. (2014). Working knowledge for collaborative water planning. International Journal of Water Governance, 2(1), 43-60.

Rogers, D. L. and Whetten, D. A. (1982). Interorganizational coordination: theory, research and implementation. Ames, IA: Iowa State University Press.

Ross, H., Grant, C., Robinson, C. J., Izurieta, A., Smyth, D. and Rist, P. (2009). Comanagement and Indigenous protected areas in Australia: achievements and ways forward. Australasian Journal of Environmental Management, 16(4), 242-252.

Skelcher, C., Sullivan, H. and Jeffares, S. (2013). Hybrid governance in European cities. Basingstoke: Palgrave Macmillan.

Sørensen, E. and Torfing, J. (2008). Theories of democratic network governance. New York: Palgrave Macmillan.

Sousa, D. J. and Klyza, C. M. (2007). New directions in environmental policy making: an emerging collaborative regime or reinventing interest group liberalism. Natural Resources Journal, 47, 377.

Sullivan, H. and Skelcher, C. (2002). Working across boundaries: collaboration in public services. Basingstoke: Palgrave Macmillan.

Susskind, L. and Cruikshank, J. (1987). Breaking the impasse: consensual approaches to resolving public disputes. New York: Basic Books.

Taylor, B. and de Loe, R. C. (2012). Conceptualizations of local knowledge in collaborative governance. Geoforum, 43(6), 1207-1217.

Thomas, C. W. (2003). Bureaucratic landscapes: interagency cooperation and the preservation of biodiversity. Cambridge, MA: The MIT Press. Retrieved from http://www.loc.gov/catdir/toc/fy035/2002071779.html.

U.S. EPA. (1992). The Watershed Protection Approach: Annual Report 1991 (No. EPA 840-S-93-001). Washington, D.C.: U.S. Environmental Protection Agency. 
van Buuren, A. (2009). Knowledge for governance, governance of knowledge: inclusive knowledge management in collaborative governance processes. International Public Management Journal, 12(2), 208-235.

Vangen, S., Hayes, J. P. and Cornforth, C. (2014). Governing cross-sector, interorganizational collaborations. Public Management Review, 17(9), 1-24.

Voets, J., Van Dooren, W. and De Rynck, F. (2008). A framework for assessing the performance of policy networks. Public Management Review, 10(6), 773-790.

Warner, J. (2007). Multi-stakeholder platforms for integrated water management. Aldershot, England and Burlington, VT: Ashgate. Retrieved from http://www. loc.gov/catdir/toc/ecip078/2006103144.html.

Weber, E. P. (2000). A new vanguard for the environment: grass-roots ecosystem management as a new environmental movement. Society and Natural Resources, 2000, 237-259.

Weber, E. P. (2003). Bringing society back in: grassroots ecosystem management, accountability, and sustainable communities. Cambridge, MA: The MIT Press.

Wegerich, K. (2007). Chapter 14: Multiplatform platforms in Uzbekistan. In J. Warner (ed.), Multi-stakeholder platforms for integrated water management (pp. xvi, 281). Aldershot, England: Ashgate. Retrieved from http://www.loc.gov/ catdir/toc/ecip078/2006103144.html.

Wesseling, R. (2011). Transnational transformations of governance: the European Union and beyond. Amsterdam, NLD: Amsterdam University Press. Retrieved from http://site.ebrary.com/lib/alltitles/docDetail.action?docID=10459445.

Wilkinson, C. (2012). Social-ecological resilience: insights and issues for planning theory. Planning Theory, 11, 148-169. 